\title{
Assessment of Correction of Female Stress Urinary Incontinence with Trans Obturator Tape; Traditional versus Tailored
}

\author{
AHMED A. EL GAMMAL, M.Sc.; SAYEDA E. ALY, M.D. and SALAH E. SHEBL, M.D. \\ The Department of Urology, Faculty ofMedicine for Girls, Al-Azhar University, Cairo, Egypt
}

\begin{abstract}
Background: Female genuine stress urinary incontinence (SUI) affects a great number of females, with important social and economic consequences. SUI is more frequent after several deliveries, after menopause as a result of changes in the urethral support or the sphincter mechanism.

Aim of Study: To compare traditional tension free transobturator tape (TOT) and surgeon tailored mesh (STM) in treatment of female stress urinary incontinence as regard of safety, efficacy, side effects, cost, and follow-up.

Patients and Method: Prospective randomized study was done on sixty three female patients were suffered SUI with determining of eligibility of the study as shown in COSORT flow chart Fig. (1) at Al Zahraa University Hospital, Al Azhar University from December 2016 to April 2019. All patients subjected to full history, general, and local examination (cases of cystocele, rectocele, or previous vaginal surgeries were excluded). Cystometrogram (CMG) was done for exclusion of uninhibited detrusor contractions, small bladder capacity ( $<250 \mathrm{CC}$ ), impaired bladder sensation, or impaired detrusor compliance. Patients with Significant Post voiding residual urine (>100 CC) assessed by ultrasonography were excluded from this study. All patients requested surgical treatment and provided informed written consent, and the study was approved by the ethical committee. With follow-up for six month postoperatively.
\end{abstract}

Results: Depending on subjective criteria obtained from the Patric questionnaire, and objective criteria from physical examination.As regards traditional tape group, 13 patients $(43.33 \%)$ were cured; two patients $(6.67 \%)$ improved with no failed cases and STM group 14 patients $(46.67 \%)$ were cured; one patient $(3.33 \%)$ improved with no failed cases ( $p$ value 0.542 , Pearson Chi-Square test).

Conclusions: TOT (outside in technique) using both STM and traditional tape are minimally invasive techniques and are equally effective and safe in treatment of pure female SUI, with short hospital stay which reduces the cost of surgery. Both techniques could be used in treatment of pure SUI with good outcome. This technique is more economical due to the cheap ordinary polypropylene mesh. So, it should be considered as a low-cost alternative to the available commercial kits in the treatment of female SUI, mainly for public health systems with few financial resources.

Correspondence to: Dr. Ahmed A. El Gammal, E-Mail: aelgammal36@gmail.com
Key Words: Female stress urinary incontinence - Surgeontailored mesh - Polypropylene mesh - TVT-O TOT - Cost.

\section{Introduction}

STRESS urinary incontinence (SUI) is the commonest subtype of urinary incontinence (UI) of female patients affecting their quality of life (QoL) and that of their families. Accounting for about $50 \%$ of the patients. Which is prevalent problem of all age, median prevalence of female UI is $27.6 \%$ [1].

The bothersome symptom of SUI may adversely affect social relationships and activities, restrict physical pursuits, impair personal hygiene and lead to avoidance of sexual relationship [2]

The AUA and Society of Urodynamics, Female Pelvic Medicine and Urogenital Reconstruction guidelines on the management of SUI recommend four types of surgical treatment: Bulking agents; midurethral sling; autologous fascia pubovaginal sling; and Burch colposuspension [3].

Midurethral sling method, standard midurethral slings (SMUSs) and single-incision mini-slings (SIMSs) were recommended for the surgical treatment of SUI in women. SMUSs have shown a high success rate [4].

\section{Patients and Methods}

Prospective randomized study was done on sixty three female patients were suffered SUI with determining of eligibility of the study using COSORT flow chart (Fig. 1). All operations were carried out at Al Zahraa University Hospital, Al Azhar University from December 2016 to April 2019. All patients subjected to full history, general, and local examination (cases of cystocele, rectocele, or previous vaginal surgeries were excluded). Cystometrogram (CMG) was done for exclusion 
of uninhibited detrusor contractions, small bladder capacity ( $<250$ CC), impaired bladder sensation, or impaired detrusor compliance. Patients with Significant Post voiding residual urine (>100 CC) assessed by ultrasonography were excluded from this study. All patients requested surgical treatment and provided informed written consent, and the study was approved by the ethical committee. Follow-up for six month post-operatively. The peri-operative data of both groups were collected, summarized, and compared using chi-square, fisher exact, or Mann-Whitney tests.

All operations were done by the same surgeon and two assistant. The patient was placed in the lithotomy position, with the thighs flexed at an angle of 120. A 16 French bladder catheter was inserted and the balloon was inflated in the bladder. The labia are retracted laterally by fixation to the skin with $3 / 0$ silk stay sutures in order to expose the vulvar vestibulum. The anterior vaginal wall is suspended with two Allis clamps on either side of the midline, $1 \mathrm{~cm}$ proximal to the urethral meatus. Submucosal saline injection to elevate the vaginal mucosa (hydrodissection) easing the dissection.

A median sagittal incision of the vaginal wall is started $1 \mathrm{~cm}$ proximal to the Urethral meatus and is continued proximally over a $1 \mathrm{~cm}$ distance. Both vaginal mucosal and sub-mucosal tissues are incised and dissected off the underlying periurethral fascia, lateral dissection with Metzenbaum scissors toward the inferior pubic ramus bilaterally was created. The internal edge of obturator foramen was identified with the tip of the index finger. Skin incision was made in or just medial to the genito-femoral fold at the base of the adductor longus tendon, approximately at the level of the clitoris. The needle was passed from the obturator incision to the vaginal incision by supination movement until palpated with the finger placed in the vaginal incision which guided it to outside through the vaginal incision.

In tailored method Polypropylene strips of about $30 \mathrm{~cm}$ length and $1 \mathrm{~cm}$ width are handly prepared by dividing the commercially available $30 \times 30$ prolene mesh (the same mesh used in hernial repair). A prolene mesh of $30 \times 30 \mathrm{~cm}$ will give about 30 tapes. Each strip can be packaged and resterilized by plasma machine.

The tape was fixed to the needle and drawn out through the thigh by pronation movement. Tension of the tape over the urethra or its twisting was avoided. Long Mayo scissors was placed between the sling and the urethra to provide a space and to avoid any tension. The tension was tested when the bladder was filled with $250 \mathrm{ml}$ of sterile fluid; the patient was asked to cough and continence assessed. Cystoscopy was performed when needed (suspected bladder or urethral injury).

The ends of the sling cut below the surface of the skin. The skin was closed with 3-0 vicryl in a sub-cuticular fashion. Finally, the anterior vaginal wall incision was closed with 3-0 vicryl in interrupted fashion. A vaginal pack soaked with povidone-iodine was placed in the vagina. The urethral catheter was re-placed into the bladder and connected to closed-bag drainage.

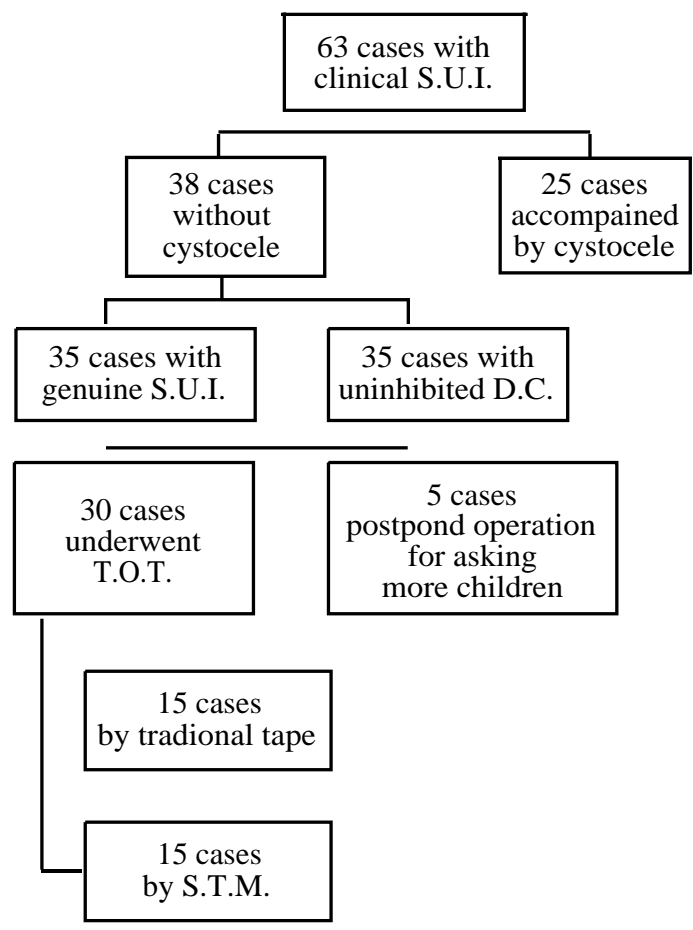

Fig. (1): CONSORT flow chart of the study.

\section{Results}

In this study we compared two groups of patients were suffered genuine stress urinary incontinence and underwent mid urethral sling Trans obturator tape (fifteen patients had traditional TOT as control group and fifteen had surgeon tailored tape as study group) to evaluate the efficacy and safety of STM in comparing to traditional TOT in relieving SUI.

The data was collected, summarized, and then statistically analyzed by using IBM SPSS v19 program.

The mean age of STM group was 41.60 \pm 6.957 years (range 30-56 years old). Seven patients aged from 31 to 40 years, six patients aged from 41 to 
50 years, and two patients aged from 51 to 56 years old. Whereas in the traditional tape group the mean age was $45.67 \pm 8.482$ years (range $30-57$ years old). Three patients aged from 31 to 40 years, six patients aged from 41 to 50 years, and six patients aged from 51 to 56 years old. $p$-value, student's $t$ test was 0.460 (statistically insignificant).

Table (1): Age categories of both groups.

\begin{tabular}{lccc}
\hline \multicolumn{3}{c}{ Group } & \\
\cline { 1 - 3 } Age category & $\begin{array}{c}\text { Surgeon } \\
\text { tailored mesh }\end{array}$ & $\begin{array}{c}\text { Traditional } \\
\text { tape }\end{array}$ & Total \\
\hline $30-39$ & 6 & 3 & 9 \\
$40-49$ & 7 & 6 & 13 \\
$50-57$ & 2 & 6 & 8 \\
\hline Total & 15 & 15 & 30 \\
\hline
\end{tabular}

$p$-value 0.310 (Eta test).

None of the patients were nulliparous. The mean number of deliveries in STM group was $4.2 \pm 1.56$ (range $2-8$ deliveries). The mean vaginal deliveries in the 30 patients were 4.1 with a range of 2-8 deliveries. Two patients only have 1 cesarean section in addition to their vaginal deliveries. The range of cesarean section (CS) in the 30 patients was 0 to 1 .

Table (2): Distribution of parity in two group of study.

\begin{tabular}{lccc}
\hline & \multicolumn{3}{c}{ Group } \\
\cline { 2 - 3 } Parity & $\begin{array}{c}\text { Surgeon } \\
\text { tailored mesh }\end{array}$ & $\begin{array}{c}\text { Traditional } \\
\text { tape }\end{array}$ & Total \\
\hline p2+0 & 5 & 1 & 6 \\
p2+1 & 0 & 2 & 2 \\
p2+2 & 1 & 0 & 1 \\
p3+0 & 2 & 3 & 5 \\
p3+1 & 3 & 2 & 5 \\
p3+2 & 0 & 2 & 2 \\
p4+0 & 0 & 2 & 2 \\
p5+0 & 2 & 1 & 3 \\
p5+1 & 1 & 2 & 3 \\
p7+1 & 1 & 0 & 1 \\
\hline Total & & 15 & 30 \\
\hline
\end{tabular}

$p$-value 0.156 (Eta test).

Seven (40\%) out of fifteen cases of study group (STM) were had ALPP ranging 101-150 ML. while eight $(53.33 \%)$ out of fifteen of control group (traditional tape) with ALPP 51-100 ML ( $p$-value 0.150, Eta test).
Table (3): Abdominal leak point pressure (ALPP).

\begin{tabular}{lccc}
\hline & \multicolumn{2}{c}{ Group } & \\
\cline { 2 - 3 } & $\begin{array}{c}\text { Surgeon } \\
\text { tailored mesh }\end{array}$ & $\begin{array}{c}\text { Traditional } \\
\text { tape }\end{array}$ & Total \\
\hline$<50 \mathrm{cc}$ & 1 & 1 & 2 \\
$51-100 \mathrm{cc}$ & 6 & 8 & 14 \\
$101-150$ & 7 & 6 & 13 \\
$151-200$ & 1 & 0 & 1 \\
\hline Total & 15 & 15 & 30 \\
\hline
\end{tabular}

$p$-value 0.150 (Eta test)

Insignificant statistical difference of both groups, mean $( \pm \mathrm{SD})$ were $20.47 \pm 3.603 \mathrm{~min} ; 19.47 \pm$ $3.226 \mathrm{~min}$. for STM and traditional tap respectively ( $p$-value 0.429 , student's $t$-test).

Table (4): Mean \pm SD of operative time of both groups.

\begin{tabular}{lcccc}
\hline Group & $\begin{array}{c}\text { Number } \\
\text { of cases }\end{array}$ & Mean & $\begin{array}{c}\text { Std. } \\
\text { Deviation }\end{array}$ & $\begin{array}{c}\text { Std. } \\
\text { Error Mean }\end{array}$ \\
\hline STM & 15 & 20.47 & 3.603 & 0.930 \\
Tradional tape & 15 & 19.47 & 3.226 & 0.833 \\
\hline
\end{tabular}

$p$-value 0.429 (student's $t$-test).

Table (5): Operative time of both groups.

\begin{tabular}{lccc}
\hline & \multicolumn{3}{c}{ Group } \\
\cline { 2 - 4 } & $\begin{array}{c}\text { Surgeon } \\
\text { Tailored Mesh }\end{array}$ & $\begin{array}{c}\text { Tradional } \\
\text { Tape }\end{array}$ & Total \\
\hline $12-18$ min & 6 & 7 & 13 \\
$19-25$ min & 9 & 8 & 17 \\
\hline Total & 15 & 15 & 30 \\
\hline
\end{tabular}

$p$-value 0.50 (Pearson Chi-Square test).

Intra-operative complications:

In both groups there are minimal intra Operative bleeding with no need for use of diathermy coagulation. And one case expected bladder injury which need to cystoscopy and exclusion of perforation. There is no urethral injury of both groups.

\section{Post-operative complications:}

There are no post operative cases with early complications as obturator hematoma (dissecting hematoma), urine retention, and high post voiding residual urine estimated by ultrasound, and De novo urgency; or late complications as vaginal erosions, vaginal discharge (infection), and wound infection.

Transient thigh pain occurs in 2cases (6.7\%) of STM and 3 cases (10\%) of traditional tape group which respond well to NSAIDs and completely resolved within one month after operation. 


\section{Post-operative follow-up:}

Post-operative follow-up carried out at 1 week, 1 month and 3 months postoperatively. At each visit all patients were subjected to Clinical assessment in the form of any distressing problem. She was asked the same questions in the pre-operative questionnaire. She was asked specifically about stress incontinence, frequency of micturition, urgency, or urge incontinence (whether persisted or developed postoperatively), voided volume, any vaginal spotting, or bleeding especially in the early postoperative period. She was asked about any vaginal pain, dyspareunia, vaginal discharge, suprapubic pain or thigh pain. She was asked about the quality of her micturition regarding strength, intermittency, deviation of stream and post voiding dribbling. Examination for the presence of discharge, vaginal erosion, chronic retention, and cough stress test.

Outcome of the procedures was evaluated depending on subjective criteria obtained from the Patric questionnaire, and objective criteria from physical examination.

As regards traditional tape group, 13 patients $(43.33 \%)$ were cured; two patients $(6.67 \%) \mathrm{im}-$ proved with no failed cases and STM group 14 patients $(46.67 \%)$ were cured; one patient $(3.33 \%)$ improved with no failed cases ( $p$-value 0.542 , Pearson Chi-Square test).

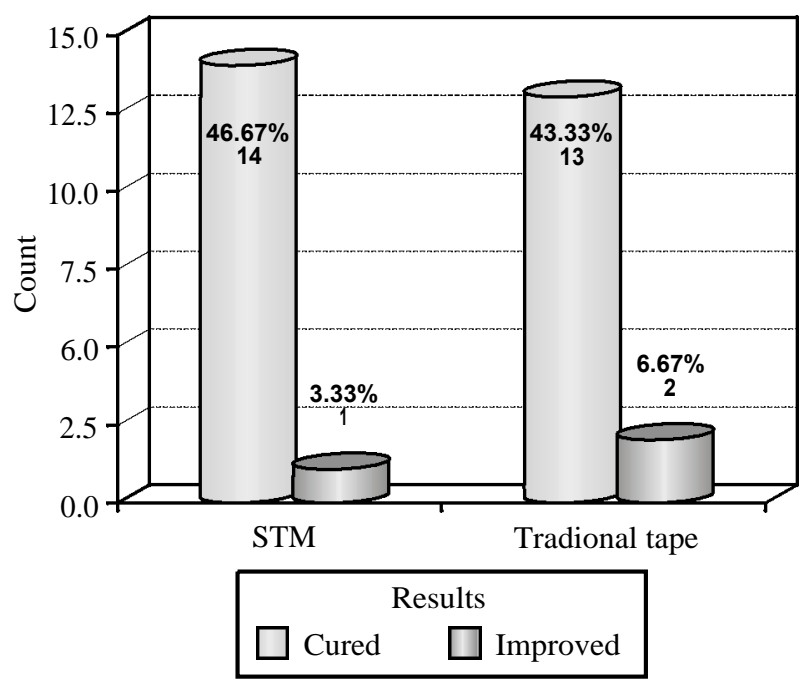

Fig. (2): Procedure outcome.

\section{Discussion}

Our two groups showed no statistically significant difference concerning age, number of deliveries, number of postmenopausal women, type, and grade of SUI. There was no statistically significant difference between the two groups in the mean abdominal leak point pressure or preoperative mean Q max.

There was no statistically significant difference in the operative time among the two groups $(20.47 \pm 3.603 \mathrm{~min} ; 19.47 \pm 3.226 \mathrm{~min}$. for STM and traditional tap respectively) ( $p$-value 0.429 , student's $t$-test).

Compared with study by Ogah et al., [5]. There is a significant statistically difference regarding the operative time when comparing our technique with the original TVT-O technique (in-out technique). Mean operative time of the original TVTO was 14min (range: 11-20) in case of isolated SUI treatment [6].

Oliveira et al., [5] reported that no bladder or urethral injury in the original TVT-O technique and thus there is no need for routine cystoscopy as in our study there was no cases with urethral or bladder injury [5]

Intraoperative cystoscopy not done except in one $(3.33 \%)$ patient of the TOT by traditional tape group with suspect bladder injury during the procedure and reveal no bladder injury. This low incidence of Intraoperative urethral or bladder injury may be due to insertion of urethral catheter and evacuation of the bladder before dissection so avoid urethral and bladder injuries, Minimal dissection, and tape should be inserted at mid urethra without tension (tension free) to avoid positioning of tape with tension place blunt instrument (forceps or scissor) between urethra and the tape during adjustment of tape.

In our study there was only one case with lateral vaginal wall injury during dissection in the early cases of study of traditional tape group (which may be due to progression in learning curve of the procedure for surgeon) which repaired immediately by vicryl 3/0; compared to Debodinance, [5] reported that perforation of the lateral wall of the vagina occurred in one case from 50 patients [7].

Lukacz and Co-workers, [5] in study included 103 patients evaluated the effect of TVT procedure on post-voiding residual urine and found that there was no clinically significant increase in postvoiding residual urine in comparison of our study we consider that post void residual urine less than $50 \mathrm{cc}$ estimated by ultrasound is insignificant there were no perioperative statistically significant difference of both group [8].

Procedure outcome differs in the literatures One of the papers used a cough stress test and a 
lack of symptoms of stress urinary incontinence as their definition of objective cure [9] one used stress test alone, [10] and one used urodynamic assessment [11].

As regards traditional tape group, 13 patients $(43.33 \%)$ were cured; two patients $(6.67 \%) \mathrm{im}-$ proved with no failed cases and STM group 14 patients (46.67\%) were cured; one patient (3.33\%) improved with no failed cases. These results were comparable to earlier studies summarized in table 13 with cure rate ranging from $83-95 \%$.

Delorme and colleagues [12] in study included 32 patients revealed a cure rate of $90.6 \%$, with a further $9.4 \%$ improvement with no failure using trans-obturator tape.

In study done by deTayrac and colleagues [12] About The outcome after TOT and TVT procedures was evaluated Their study included 30 TOT procedures. The cure rate in their study for TOT cases was $90 \%$, with a further $3.3 \%$ improvement, and a failure rate of $6.7 \%$. The mean follow-up was 12 months.

Cindolo et al., [12] reported that $96 \%$ of cases satisfied by result of surgery in their study which was conducted on 80 women complaining of SUI. The mean follow-up was 4 months [9]

Evaluation of outcome of TOT procedure in 94 patients with SUI One year follow-up. By Mellier and colleagues, [12] revealed $95 \%$ cure rate, with a further $4 \%$ improvement, and a failure rate of $1 \%$. The mean follow-up was 12 months ranging from 2-20 months.

Thom and Klutke, [12]. In study on the outcome after TOT procedure included 47 women complaining of SUI. The cure rate in their study was $96 \%$. The mean follow-up was 18 months.

\section{Summery and Conclusion:}

TOT (outside in technique) using both STM and traditional tape are minimally invasive techniques and are equally effective and safe in treatment of pure female SUI, with short hospital stay which reduces the cost of surgery. Both techniques could be used in treatment of pure SUI with good outcome.

These results are also comparable with the results of TOT that were reported in the previous literature.

Furthermore, this technique is more economical due to the cheap ordinary polypropylene mesh.
So, it should be considered as a low-cost alternative to the available commercial kits in the treatment of female SUI, mainly for public health systems with few financial resources.

Randomized controlled studies with a longer duration of follow-up are needed to confirm our results.

Conflict of interest: None.

Funding source: None.

\section{References}

1- CARDOZO L.: New developments in the management of stress urinary incontinence. BJU International, 94 (s1): p. 1-3, 2004.

2- FULTZ N.H., et al.: Burden of stress urinary incontinence for community-dwelling women. Am. J. Obstet. Gynecol., 189 (5): p. $1275-82,2003$

3- KOBASHI K.C., et al.: Surgical Treatment of Female Stress Urinary Incontinence: AUA/SUFU Guideline. J. Urol., 198 (4): p. 875-883, 2017.

4- HSIAO S.M., T.C. CHANG and H.H. LIN: Risk factors affecting cure after mid-urethral tape procedure for female urodynamic stress incontinence: Comparison of retropubic and transobturator routes. Urology, 73 (5): p. 981-6, 2009.

5- OLIVEIRA R., et al.: Short-term assessment of a tensionfree vaginal tape for treating female stress urinary incontinence. BJU International, 104 (2): p. 225-228, 2009.

6- OGAH J., J.D. CODY and L. ROGERSON: Minimally invasive synthetic suburethral sling operations for stress urinary incontinence in women. Cochrane Database Syst. Rev., (4): p. Cd006375, 2009.

7- DEBODINANCE P.: [Trans-obturator urethral sling for surgical correction of female stress urinary incontinence: Outside-in (Monarc) versus inside-out (TVT-O). Are both ways safe?]. J. Gynecol. Obstet. Biol. Reprod (Paris), 35 (6): p. 571-7, 2006.

8- LUKACZ E.S., K.M. LUBER and C.W. NAGER: The effects of the tension-free vaginal tape on voiding function: a prospective evaluation. Int. Urogynecol. J. Pelvic Floor Dysfunct, 15 (1): p. 32-8; discussion 38, 2004.

9- CINDOLO L., et al.: Tension-free transobturator approach for female stress urinary incontinence. Minerva Urol. Nefrol., 56 (1): p. 89-98, 2004.

10- ROUMEGUÈRE T., et al.: Trans-Obturator Vaginal Tape (TOT<sup>\&\#xae;</sup>) for Female Stress Incontinence: One Year Follow-Up in 120 Patients. European Urology, 48 (5): p. 805-809, 2005.

11- BARRY C., et al.: Does the MONARC transobturator suburethral sling cause post-operative voiding dysfunction? A prospective study. Int. Urogynecol. J. Pelvic Floor Dysfunct, 17 (1): p. 30-4, 2006

12- DELORME E., et al.: [Transobturator tape (Uratape). A new minimally invasive method in the treatment of urinary incontinence in women]. Prog. Urol., 13 (4): p. 656-9, 2003.56-9, 2003 


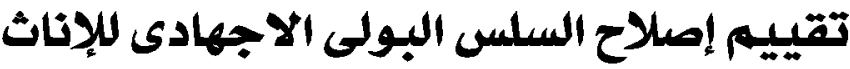

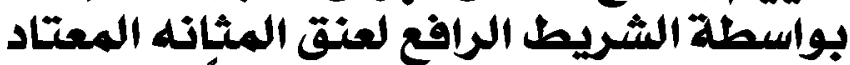 مقارنة بالهصمي يلدوياً}

السلس البولى هو من أكثر المشاكل الصحية شيوعاً وخاصة فى فئة النساء اللواتى مررن بتجربة الولادة مراراً أوتعرضن لولادة عسرة وله آثَ كبير في المجال الاجتماعى.

ويعرف سلس البول بأنه عدم القدرة على التحكم فى البول مما يؤدى إلى تسرب البول لا إرادياً والذى يمثل مشكلة صدية وإجتماعية.

$$
\text { ولسلس البول أنواع متعددة أكثرها شيوعاً: }
$$

ا - السلس البولى الاجهادى: وهو فقدان القدرة على التحكم فى البول لا إرادياً مع أى مجهود مفاجئ مثل الضحك والسعال والعطس.

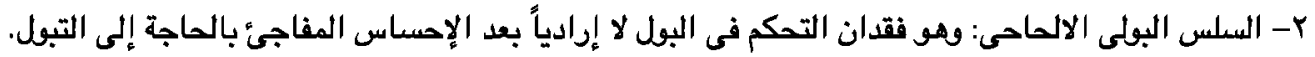
r- السلس البولى المختلط: وهو مزيج من السلس الإجهادى والسلس الالالحاحى. ع- سلس البول الفائض: ويحدث عندما تعجز المثانة عن التفريخ الكامل مما يتسبب فى تسرب البول الفائض بشكل مستمر وهذا النوع من

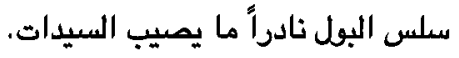

0- سلس البول الوظيفى: وهذا ينتج من عوامل خارج المثانة مثل الوهن البدنى الشديد ويحدث هذا النوع فى الشيخوخة المتقدمة. طرق علاج السلس البولى الاجهادى تشمل: تدريب عضلات الحوض (العلاج الطبيعى لعضلات الحوض)، العلاج بالالوية، الشريط الرافع لعنق المثانة، الجراحة، وحديثاً العلاج بالليزر الهدف من البحث: المقارنة بين علاج حالات سلس البول الاجهادى بواسطة الشريط المعتاد الرافع لعنق المثانة والشريط الذى يتم تصميمه يلوياً بواسطة الجراح من حيث الفعالية والاعراض الجانيية والتكلفة والمتابعة بعد العملية.

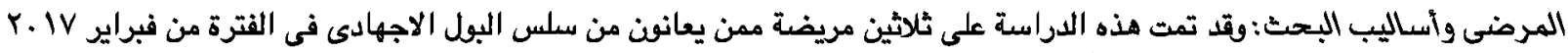

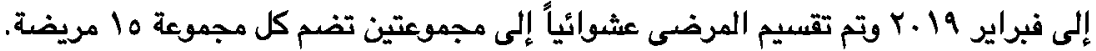
- مجموعة (أ) وتم علاج المرضى بواسطة الشريط الرافع لعنق المثانة المعتاد. - مجموعة (ب) وتم علاج المرضى بواسطة الثريط الرافع لعنق المثانة المصمم يدويطاً. وقد خضع جميع المرضى لاخذ التاريخ المرضى والكثف الإكلينيكى وتم عمل الفحوصات اللازمة لهم وتشمل: - التحاليل المعملية تحليل بول، صودة دم كاملة، وظائف كلى وكبد وقياس معدلات النزيف. - الموجات فوق الصوتية.

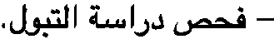

وتم تقييم جميع المرضى قبل وأثناء وبعد العملية مع أخذ الملاحظات وعمل الجداول اللازمة للوصصل إلى النتائج المطلوبة.

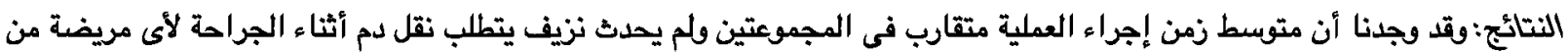

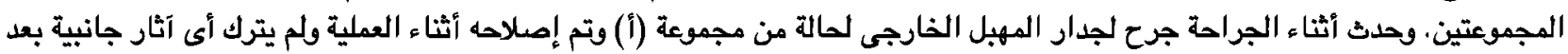

أثتبت الدراسة أن كلا الطريقتين فعالة فى علاج حالات السلس البولى الاجهادى من حيث نسب النجاح والتحسن والفثل. وقد أثثبت البحث تقارب نسب النجاح ونسب المضاعفات لكلا العمليتين من النسب المسجلة عالياً.

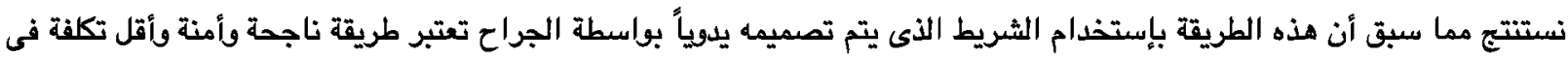

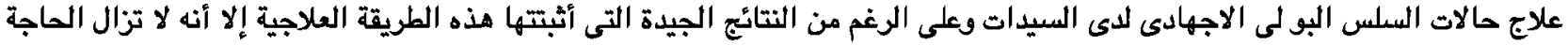
إلى إجراء المزيد من الأبحاث خلال فترات زمنية أطول وعدد أكبر من المرضى. 